\title{
UNDERSTANDING THE BEHAVIOURAL INTENTION TO ADOPT INTERNET BANKING: AN INDIAN PERSPECTIVE
}

\author{
Garima Malik ${ }^{1 *}$, \\ Dharmendra Singh², \\ Nikola Stakić ${ }^{3}$ \\ ${ }^{1}$ Amity University, \\ Uttar Pradesh, India \\ ${ }^{2}$ Modern College of Business and \\ Science, \\ Muscat, Oman \\ ${ }^{3}$ Singidunum University, \\ Belgrade, Serbia
}

\begin{abstract}
:
Internet banking gives banks colossal advantages as far as cost reserve funds, better client connections, and separate contributions from the opposition. This study expects to recognize the components that essentially influence the intention of bank clients to utilize Internet banking administrations in India. The examination proposed a complete model called Internet Banking Adoption in India, which was an implicit part based on the "Brought together Theory of Acceptance and Use of Technology" (UTAUT) and three extra factors that were recognized as setting delicate. A selfmade survey with 100 samples on the impact of behavioural intention to adopt Internet Banking was conducted using surveys available on the Internet. For further analysis, a statistical tool like Chi-Square, correlation and regression were performed on SPSS software. According to the TAM Model, perceived trust, perceived risk and perceived ease of use was taken into consideration to rate the behavioural intention for adopting Internet Banking in day-to-day life.
\end{abstract}

Keywords:

internet banking, behavioural factors, adoption, India.

\section{INTRODUCTION}

One of the business areas that has been fundamentally affected by the advancement of the Internet is banking. With web-based banking, banks can understand clear advantages, for example, lower working costs, fast market development, compelling client relationships with the board, and better help. Internet banking has been demonstrated to be valuable for banking clients as far as cost reserve funds, time investment funds, brisk grievance goal, and better banking administrations, accordingly expanding their banking efficiency. The reasoning behind the innovative turn of events and upset in banking in India is that in the course of many recent years, banking as help has developed from gracefully headed to request driven. Banks in India have acknowledged in the post-advancement time that to remain serious and furnish their customers with the best administrations, they have to utilize the most recent innovation. Generally, banks have extended their customary branches to increase a more prominent piece of the overall industry. Along these lines, the new movement of mechanical advancement gave banks progressive occasions to give their banking administrations, for example, ATMs, Internet banking, versatile banking etc. A portion of these advancements has been broadly embraced by all client fragments of the bank. Paces of the utilization of different channels were low, particularly in non-industrial nations like India, where the Internet entrance is developing quickly.
Correspondence:

Garima Malik 


\section{BEHAVIOURAL INTENTION AND DETERMINANTS OF ADOPTION}

The "Technology Acceptance Model (TAM), Reasoned Action Theory (TRA), Planned Behaviour Theory (TPB), and Diffusion Theory of Innovation (DOI) are all models and theories that are used in information systems to study technology adoption. This study's postulates are based on TPB (Theory of Perceived Behaviour) and diffusion, according to the theory of innovation (DOI), state that a person's intention to use Internet banking is determined by three factors: attitude, control of perceived behaviour and subjective norms. Attitude is explained by sub-constructions of perceived utility, perceived ease of use, and perceived safety risk, perceived behavioural control" is analysed by sub-constructions of self-efficacy and enabling environment, and finally, subjective norms are explained by sub-constructions of social influence.

In TAM and its variants, attitudes towards the use of technology are seen as an important precursor of behavioural intention, while social variables are explicitly neglected and people are expected to keep them in mind. Perceived ease of use is a cognitive belief that can be defined as the degree of confidence that the use of a particular structure will be stress-free.

Concerns about trust and security have been identified as the main obstacles to the adoption of Internet banking. The introduction of technological innovations such as mobile banking and Internet banking means that financial institutions will need to think about how to mitigate operational risks. Another issue with Internet banking is the issue of trust in web-based banking. Morgan and Hunt (1994) depicted trust as the establishment, everything being equal. Trust is the readiness to get powerless against others (Rousseau et al. 1998). This weakness has gotten more hazardous and questionable, particularly with regards to cash (McKnight and Chervany, 2001). The absence of trust influences the ability of clients to purchase items and administrations over the Internet (Friedman et al., 2000), particularly in the Middle East (Alkailani and Kumar, 2012; Alkailani, et. Al, 2013). Trust has been one of the obstructions that keep individuals from utilizing innovation (Nor and Pearson, 2007) due to the hacking of classified private data and wholesale fraud. This further affected the degree of customer trust in Internet banking (Kramer, 1999). More prominent dependence on Internet banking will lessen follow-up and case costs (Fortin et al., 2004). Trust altogether impacts the eagerness or aim of buyers to utilize Internet banking. (Suh et al., 2007). In view of the conversation over, the analyst predicts that there is a factual connection between purchaser certainty and Internet banking
As financial banking administrations move away from banking specialist organizations and banks become more virtualized, distant access innovations and Internet foundation have driven clients to lose direct association with bank representatives, subsequently, that has constrained them to virtualize the new assistance (Bauer and Hein, 2006). This new experience and the new financial exchange preparing climate will make dread and vulnerability among clients.

One of the theories of technology adoption used to define self-efficacy is the theory of planned behavior. "Selfefficacy" refers to people's beliefs in their ability to perform certain actions. The Theory of Planned Behaviour, which is an extension of TRA, removes the weakness of the control mechanics. TPB extends TRA (Theory of Intelligent Action and emphasis on the control aspect of behaviour. According to the TPB, human actions are guided by three types of considerations: (a) behavioural beliefs about the likely outcomes of the behavior and the evaluation of those outcomes; (b) normative perceptions about the normative expectations of others and the motivation to satisfy those expectations; and (c) control perceptions about the resources and capabilities that the individual has (or does not have), as well as anticipated barriers or impediments to the performance of the target behavior."

\section{LITERATURE REVIEW}

The explanations behind the protection from electronic banking featured that "trouble of utilization", "pointless use" and "security concerns" are key variables. (Mahmud, 2016). This investigation looks at how clients see and use Internet banking (IB) in Jordan. An all-encompassing model dependent on the Technology Adoption Model (TAM) was created and three additional builds were added to the model; to be specific Presumed Risk (PR), Perceived Confidence (PT), and Bank Strength (BC). This investigation experimentally tests the capacity of the model to anticipate client goals to acknowledge and utilize Internet banking. The outcomes that uphold the all-inclusive TAM show and affirm its vigour in foreseeing the client's aim to acknowledge and utilize Internet banking. (Saibaba S., 2014) inspected the components affecting the acknowledgment of Internet banking administrations by banking clients in Hyderabad. Exploration has indicated that clients' inspirational mentalities towards Internet banking innovation can impact their goals to utilize it. This examination additionally found that Indian bank advertisers need to convey the advantages of web-based banking through different promotion crusades, making banking sites straightforward, advantageous, and sufficiently secure to urge their customers to do internet banking. (Singhal \& Padhmanabhan, 2008) inspected the 
principle factors that drive Indian bank clients to utilize Internet banking dependent on their view of different Internet-related applications. They found that utility solicitations, security, reserves move, utility transactions, and ticket reservations were the top components, with over half of respondents concurring that web-based banking is advantageous, adaptable, and gives transaction-related advantages. Khare et al (2010) analyzed the function of character qualities in Internet banking appropriation in India. It is accounted for that singular contrasts between banking clients will impact their view of the properties of web-based banking and its advantages. The suggestion is that Indian banks need to consider singular contrasts when planning and improving web-based banking destinations as this will encourage dynamic. (Shah, 2011) directed an examination to decide the components that impact the spread of Internet banking in Gujarat, India. The outcomes demonstrated that banking needs, seen danger, security, and cost investment funds were the primary elements driving clients to utilize Internet banking. Moreover, the examination found that Indian banks need to instruct their clients about Internet banking administrations and their advantages so they are better acknowledged by clients. Another significant finding of this examination was the effect of the information on Internet banking administrations and its advantages in its selection. (Ramayah \& Rouibah, 2009) analyzed the elements impacting an individual's expectation to utilize Internet banking in Penang utilizing TAM utilizing extra factors including related knowledge, transaction volume, earlier framework preparing, and outside weights. Exploration has demonstrated that apparent value and saw convenience significantly affect the client's aim to utilize internet banking.

Current Internet banking clients have discovered this new banking channel to be a more advantageous type of banking administrations than non-clients. Different boundaries that were seen as essentially unique in the two gatherings were similarity - PC capability and multifaceted nature. The issues of openness, security, and seen monetary advantages of Internet banking didn't contrast among clients and non-clients. (Tan \& Teo, 2000) applied the Decomposition Theory of Planned Behaviour (DTPB) model to comprehend the significant variables that decide how clients mean to utilize Internet banking in Singapore. With regards to the examination, the free factors were recognized: demeanour, abstract standards, and saw conduct control, which influence the reliant variable, that is, the expectations to utilize Internet banking administrations. This investigation found that disposition conviction and saw social control factors altogether impacted clients' goals to utilize internet banking. Among the relationship factors, unpredictability alone didn't significantly affect business insight.
On account of apparent social control, mechanical help was not a critical factor. A significant finding of this study is that the impact of companions, family, or associates on the reception of Internet banking administrations, that is, abstract standards, on the expectations to utilize Internet banking administrations was not critical.

\section{METHODOLOGY AND ANALYSIS}

This empirical research evaluates the importance of behavioural aspect to adopt the internet banking. In this competitive and digital era banks are also focusing on attracting as well as retaining their customers for longer periods of time. To save the customer time and money banks introduce e-banking which consists of internet banking and mobile banking and ATM. This study basically highlights the factors that influence the adoption of internet banking in different settings. These identified factors provide the edge over the others on the basis that banks can develop their strategy to attract their customers. Since the main objective of the project is to study the impact of behavioural intention to adopt internet banking, the exploration procedure embraced is basically founded on essential 27 information, with which you can gather the latest and exact direct data. Secondary information data was utilized to help essential information when necessary. For the purposes of this study, an appropriate random population sample (100 respondents) was selected based on convenience. Some data was also obtained through online surveys using Google Docs and forms.

A survey method is used to collect the responses from Northern Capital Region (NCR) India. The random sampling method is used to select the 100 respondents. SPSS statistical software is used for the further analysis accordingly to the objectives of the research. The questionnaire consists of two parts. The first part of the questionnaire having questions related to the demographic and behavioural characteristics of the respondents and second part of the questionnaire consists of statements related the adoption of internet banking.

Table 1: Reliability Test

\begin{tabular}{cc}
\hline “Cronbach's Alpha & N of Items" \\
\hline .823 & 15 \\
\multicolumn{2}{c}{ Source: Authors' calculation }
\end{tabular}

Cronbach's Alpha reliability test is done to determine that the variables are internally consistent. As Cronbach's Alpha is .823, which is greater than .7, it signifies that the data collected is reliable and can be used for further analysis (Table 1). 
To study the association between analysis for Gender and Factors for adoption behaviour towards Internet Banking, the result showed the value for Chi-square of analysis for Gender and Factors for adoption behaviour towards Internet Banking is significant at 0.01 level, $\left(\chi^{2}=8.049, \mathrm{p}=0.03\right)$.

Table 2. Chi-Square Analysis

\begin{tabular}{lccc}
\hline & Value & df & $\begin{array}{c}\text { Asymptotic } \\
\text { Significance } \\
\text { (2-sided) }\end{array}$ \\
\hline "Pearson Chi-Square & $8.049^{a}$ & 8 & .429 \\
\hline Likelihood Ratio & 8.955 & 8 & .346 \\
\hline $\begin{array}{l}\text { Linear-by-Linear } \\
\text { Association }\end{array}$ & .000 & 1 & .997 \\
\hline N of Valid Cases" & 100 &
\end{tabular}

The value for Chi-square of analysis for Gender and is significant at 0.01 level, $\left(\chi^{2}=8.049, p=0.03\right)$. Factors for adoption behavior towards Internet Banking

Table 3. Regression between behavioral intentions towards Internet Banking and Perceived trust, Perceived risk and Perceived Ease of Use

\begin{tabular}{|c|c|c|c|c|}
\hline \multicolumn{5}{|c|}{ Model Summary } \\
\hline “Model & $\mathrm{R}$ & R Square & Adjusted R Square & $\begin{array}{l}\text { Std. Error of the } \\
\text { Estimate" }\end{array}$ \\
\hline 1 & $.871^{\mathrm{a}}$ & .759 & .732 & .71698 \\
\hline
\end{tabular}

Source: Authors' calculation

The regression analysis is used for the analysis of impact between behavior intentions towards Internet Banking and Perceived trust, Perceived Risk and Perceived Ease of Use.

Table 4. Anova Table
The values of $\mathrm{R}$ square (.759) and adjusted R square (.732) are close, which signifies that data collected is adequate.

\begin{tabular}{|c|c|c|c|c|c|c|}
\hline & \multicolumn{6}{|c|}{ ANOVA $^{\mathrm{a}}$} \\
\hline & Model & Sum of Squares & $\mathrm{df}$ & Mean Square & $\mathrm{F}$ & Sig. \\
\hline \multirow[t]{3}{*}{1} & Regression & 143.831 & 10 & 14.383 & 27.979 & $.000^{\mathrm{b}}$ \\
\hline & Residual & 45.751 & 89 & .514 & & \\
\hline & Total & 189.582 & 99 & & & \\
\hline \multicolumn{7}{|c|}{ a. Predictors: (Constant), PEO3, PT1, PR1, PT2, PT4, PR3, PT3, PR2, PEO1, PEO2 } \\
\hline \multicolumn{7}{|c|}{ b. Predictors: (Constant), PEO3, PT1, PR1, PT2, PT4, PR3, PT3, PR2, PEO1, PEO2 } \\
\hline
\end{tabular}

\section{Source: Authors' calculation}

The regression value between behavior intentions to adopt Internet Banking and Perceived trust, Perceived Risk and Perceived Ease of Use is 143.831 at 0.01 level with Factors for adoption behavior towards Internet Banking as a dependent variable and Factors for adoption behavior towards Internet Banking and Perceived trust, Perceived Risk and Perceived Ease as Independent variables. As the p-value or significance value is $<0.05$ i.e. .000 it signifies that behavior intentions towards Internet Banking have positive effect on Perceived trust (PT), Perceived Risk (PR) and Perceived Ease of use (PEO).

The result showed that the regression value between behaviour intentions to adopt Internet Banking and PT PR and PEO is 143.831 at 0.01 level with Factors for adoption behaviour towards Internet Banking as a dependent variable and Factors for adoption behaviour towards 
Internet Banking and Perceived trust, Perceived Risk and Perceived Ease as Independent variables. As the p-value or significance value is $<0.05$ i.e. .000 it signifies that behaviour intentions towards Internet Banking has positive effect on Perceived trust(PT), Perceived Risk(PR) and Perceived Ease of use(PEO)

\section{CONCLUSION}

A self-made survey with 100 sample on the impact of behavioral intention to adopt Internet Banking was conveyed using surveys available on the web. A descriptive analysis based on demographic data was performed. Key demographic data included their age, gender, marital status, and, occupation. For an in-depth analysis, all the important factors related to the topic were rated on the Likert scale from 1 to 5 with the point categorically from strongly disagree to strongly agree on the scale. For further analysis, a statistical tool like Chi-Square, correlation and regression was performed on SPSS software. The outcomes revealed that the participants for the study were under 25 years of age, i.e., the youths, out of which mostly were males. There was an equivalent number of single people and married couples who took part in this study and the maximum were students by occupation. In terms of preference behavior towards Internet banking, maximum respondents voted for a Yes option, and maximum respondents were found using Internet Banking on a daily basis. It is depicted that on average, people have been able to successfully and willingly adopt internet banking in day-to-day life. According to the TAM Model, PT, PR, POE were taken into consideration to rate the behavioral intention for adopting Internet Banking in day-to-day life. On average, people were actually willing to adopt the modern behavior of Internet Banking and can rely on it; they find it easy to use and can also take the minimal amount of risk in terms of adoption of internet banking.

Knowledge of Internet banking services is very important for customers to switch to Internet banking. To attract more potential customers, bank clerks at branches should provide information about Internet banking. The information should include time savings, convenience, anywhere, anytime, at low cost. The Internet banking framework must be underlying in such a way that clients can confide in it. Your internet banking framework ought not to be dependent upon startling personal time or regular dissents of administration. Furthermore, banks ought to give their clients complete help when confronted with the issue of internet banking. Banks should regularly conduct online banking customer surveys and opinions to attract more Internet banking customers. Banks must implement a high-quality Internet infrastructure to attract more potential customers.

\section{LITERATURE}

Alalwan, A., Dwivedi, Y., Rana, N., Algharabat, R. (2018). Examining factors influencing Jordanian customers' intentions and adoption of internet banking: Extending UTAUT2 with risk. Journal of Retailing and Consumer Services, 40, 125-138.

Alkailani, M. (2016). Factors Affecting the Adoption of Internet Banking in Jordan:. Journal of Marketing Development and Competitiveness Vol. 10 (1), 39-52

Bashir, I., Madhavaiah, C. (2015). Consumer attitude and behavioural intention towards Internet banking adoption in India. Journal of Indian Business Research 7(1), 67-102.

Ndubisi, N. O. (2006). Customers' perceptions and intention to adopt Internet banking: the moderation effect of computer self-efficacy. AI \& Society, 21(3),, 315-327.

Rahi, S., Othman Mansour, M.M., Alghizzawi, M., Alnaser, F.M. (2019), "Integration of UTAUT model in internet banking adoption context: The mediating role of performance expectancy and effort expectancy", Journal of Research in Interactive Marketing, Vol. 13 No. 3, pp. 411-435.

Ramayah, T., Rouibah, K. (2009). User Acceptance of Internet Banking In Malaysia: Test of Three Competing Models. International Journal of E-Adoption 1(1), 1-19.

Saibaba, S. Murthy, T. N. (2013). Factors influencing the behavioural intention to adopt Internet banking: An empirical study in India. Researchers World: Journal of Arts, Science and Commerce, 4(4).

Saibaba, S. (2014). Factors Influencing Customers' Intentions to Use Internet Banking: Model Development and Test. International Journal of Innovative Technology \& Adaptive Management (IJITAM), ISSN, 2347-3622.

Shah, A. (2011). Factors Influencing Online Banking Customer Satisfaction and Their Importance in Improving Overall Retention Levels: An Indian Banking Perspective. Journal of Information \& Knowledge Management 1(1): 45-54.

Singhal, D., Padhmanabhan, V. (2008). A Study on Customer Perception Towards Internet Banking: Identifying Major Contributing Factors. Journal of Nepalese Business Studies 5(1), 101-111.

Tan, M., Teo, T. S. (2000). Factors Influencing the Adoption of Internet Banking,. Journal of the Association for Information Systems: Vol. $1:$ Iss. 1 , Article 5. 